\title{
Research on the Rationality of Precision Poverty Alleviation
}

\author{
Yuyin Li \\ Sichuan University of Arts and Science, Dazhou, China \\ Email:47872614@qq.com
}

How to cite this paper: Li, Y.Y. (2019) Research on the Rationality of Precision Poverty Alleviation. Open Journal of Social Sciences, 7, 347-354.

https://doi.org/10.4236/jss.2019.74027

Received: March 26, 2019

Accepted: April 25, 2019

Published: April 28, 2019

Copyright (c) 2019 by author(s) and Scientific Research Publishing Inc. This work is licensed under the Creative Commons Attribution International License (CC BY 4.0).

http://creativecommons.org/licenses/by/4.0/

\begin{abstract}
Precision poverty alleviation is the further deepening of poverty alleviation work and conforms to the theoretical logic of poverty alleviation. This dissertation explores the rationality of Precision poverty alleviation from three aspects: the connotation of Precision poverty alleviation, the internal logic of poverty alleviation, and the practical necessity of poverty alleviation.
\end{abstract}

\section{Keywords}

Poverty, Precision Poverty Alleviation, The Essence of Socialism

\section{Introduction}

Precision poverty alleviation has been fully implemented for nearly three years, and the effect proves this policy's correctness. Every correct policy is based on profound theoretical foundation, and as a general policy of the country, it has profound theoretical origin and foundation. However, the research on Precision poverty alleviation in the theoretical circle still lags behind the pace of practice, so the research on Precision poverty alleviation has become an urgent issue for the academic circle.

\section{Research about the Rationality of Precision Poverty Alleviation}

In November 2013, when Xi Jinping, the general secretary visited Xiangxi, Hunan province, he pointed out that "poverty alleviation should be based on facts and in line with local conditions. Precision poverty alleviation is not only a sentence." [1] Precision poverty alleviation was proposed firstly. The proposal of "Precision poverty alleviation" is undoubtedly the crystallization of the collective wisdom of the CPC central committee with Xi Jinping as general secretary, a 
major measure to ensure the building of a moderately prosperous society in all respects by 2020 , a concrete embodiment to the result of reform and development shared by all the people, and an innovation in the theory of poverty alleviation under socialism with Chinese characteristics.

As an innovative poverty alleviation theory, Precision poverty alleviation is far from enough in terms of research breadth and depth, and there is a big gap between theoretical research and practical operation. At present, some scholars analyze and study the dialectical thinking logic of Precision poverty alleviation from the perspective of philosophy. For example, Xie Pingan's Philosophical Thinking On "Precision Poverty Alleviation" describes the specific meaning, characteristics, methods and practical significance of "Precision poverty alleviation" from a philosophical perspective [2]. The author also thinks that accurately grasp internal cause and external cause for poverty alleviation, the poor people and the poor areas is the internal cause, support units, cadres and policy is the external cause, "only to catch the regional poverty internal cause, both the external cause at the same time, by flexible and reasonable measures, suit the remedy to the case, can really make in the phase of poverty population out of poverty." [2] It from the particularity of contradiction and all from the reality to discuss the precision of poverty alleviation philosophical method. Some scholars think about Precision poverty alleviation from the perspective of theory and reality. For example, Wang Sitie believes that Precision poverty alleviation is a poverty alleviation method that USES scientific and effective procedures to precisely identify, precisely assist and precisely manage poverty-stricken objects according to different environments and conditions of poverty-stricken farmers in different poverty-stricken areas [3]. Li Kun, Ye XingJian in Precision Poverty Alleviation in Rural Areas: Theoretical Basis and Practical Situation Analysis claim that accurate poverty alleviation of poverty reduction concept such as is both a pro-poor type means of poverty reduction from traces the rights poverty of theory and inclusive growth poverty concept, the concept of participatory poverty alleviation, and collaborative anti-poverty theory, trickle-down theory and pro-poor theory, and pay attention to the cooperative poverty alleviation multi-party participation, coordination [4]. Wang Sangui and Guo ZiHao believe that the most basic definition of Precision poverty alleviation is that poverty alleviation policies and measures should be Precision at the truly poor families and population, and various factors and obstacles leading to poverty should be fundamentally eliminated through Precision assistance to the poor population, so as to achieve the goal of sustainable poverty alleviation [5].

The above studies provide a certain theoretical basis for the legitimacy, rationality and realistic needs of Precision poverty alleviation, and play a theoretical guiding role in the in-depth promotion of Precision poverty alleviation. However, there are still many problems worth thinking and studying. Such as "What is the effect to promote accuracy the main contradiction and win the battle for poverty alleviation, What is the main aspect of contradiction", "the relationship between helping work and conditions for poverty alleviation in poverty-stricken 
areas, the relationship between the people's willingness and ability to shake off poverty, the relationship between external support for good internal dynamics, the relationship between accomplish the task of tackling and stabilizing the relationship between poverty and stability, the relationship between poverty alleviation goal and helping practice" [6] and so on, these all need to think about and study, change only questions without the answer as soon as possible.

\section{Connotation of Precision Poverty Alleviation}

General Secretary Xi Jinping's idea of Precision poverty alleviation is the inheritance and innovation of Marxist poverty alleviation theory. Since the founding of new China, China has attached great importance to poverty reduction. The development history of China's socialist construction is, in essence, the history of eliminating poverty, improving people's livelihood and achieving common prosperity. From 1949 to 1978 on poverty reduction the exploration of the road, or in the mid-1980s began to implement the seven-year priority poverty alleviation program (1994-2000), and "China's rural poverty alleviation and development program (2001-2010)" and "China's rural poverty alleviation and development program (2011-2020)", the implementation plan of mass poverty, poverty alleviation and development has been accompanied by China's socialist construction and reform and opening up. By 2014, we had lifted more than 600 million people out of poverty, becoming the first country in the world to achieve the UN millennium development goals and halve the number of people living in poverty. However, by the end of 2014, there were still over 70 million people living in poverty. At present, China's poverty alleviation and development has shifted from solving the problem of food and clothing as the main task to consolidating the fruits of food and clothing, speeding up poverty alleviation and becoming rich, improving the ecological environment, enhancing the ability of development, narrowing the development gap, and entering a new stage of well-off life in an all-round way. At present, we are still faced with the arduous task of poverty alleviation and development.

Therefore, the central government has proposed Precision poverty alleviation. Precision poverty alleviation is to achieve "precise target of poverty alleviation, precise project arrangement, precise use of funds, precise measures to households, precise sending of people to villages and precise effect of poverty alleviation" [7]. To be specific, "precise object of support" means to find out exactly which poor people are the most in need of support. "Precise project arrangement" means that policies should be applied according to people and places, poverty reasons and types of poverty, and different situations should be differentiated to achieve precise drip irrigation, Precision treatment and symptomatic medicine. "Precise use of funds" means to focus on poverty alleviation programs, make scientific arrangements for their use, and make precise use of funds to ensure that poverty alleviation funds can give full play to their best benefits. "Precise measures to households" means to make plans, implement policies and 
strengthen pertinence according to people and households. "Accurate village staffing" refers to the selection of outstanding cadres with good ideas, upright style, strong ability, understanding of local conditions and willing to serve the masses to serve as the first secretary and village cadres in rural grassroots according to the conditions of the poor villages, the causes of poverty, leading industries and other factors. "Precise effect of poverty alleviation" means that measures should be taken according to local conditions to fundamentally realize the stable poverty alleviation of poor households and truly shake off poverty. These six precision is to systematically solve the problems of "who to support", "who to help", "how to help", "how to withdraw" and so on.

Precision poverty alleviation can completely solve such problems as unclear foundation, inaccurate target and poor effect in poverty alleviation work. Therefore, the core content of Precision poverty alleviation is to "identify the real poverty, help the real poverty, and really help the poor", and its essence is to coordinate various poverty alleviation resources to better target the poor target population. To identify the real poor and help the real poor is to identify the quasi-poor population and target the poor population. "Genuine poverty alleviation" means to pool various poverty alleviation resources, adopt scientific and effective measures and carry out Precision work. Therefore, Precision poverty alleviation mainly consists of two parts, namely, identifying the poor population and targeting poverty alleviation resources, and adopting Precision treatment. The identification of the poor population is mainly through a series of poverty alleviation work mechanisms, procedures and tools, such as "five batches", to accurately identify the specific poor population, and through the establishment of poverty alleviation information network system for dynamic management of the poor population. Targeting poverty alleviation resources is to invest poverty alleviation resources in a certain way on the basis of effective identification of the poor population, so as to promote the economic development of the target region and the poverty alleviation and enrichment of the target population.

\section{The Inherent Logic of Poverty Alleviation}

Poverty, as an economic phenomenon in social life, is one of the major problems affecting human progress in the process of human development. It has troubled many countries in the world, both developed and developing countries, and has been an important area of common concern to governments and academia of all countries. In September 2000, at the United Nations millennium summit, world leaders agreed on a set of time-bound targets and targets for the year 2015 for the eradication of poverty, hunger, disease, illiteracy, environmental degradation and discrimination against women. Among them, the eradication of extreme poverty and hunger is the primary goal of development. Therefore, the eradication of poverty is a common task facing mankind. Although the causes of poverty are very complex, the eradication of poverty is a common value of mankind. However, by 2015, poverty still exists in every corner of the world. 
Marx believed that the history of social development is the process of natural history, and man formed the natural social history by using and transforming nature in practice, and man is the product of nature. "Man is directly a natural being" "He is in his environment and develops together with the environment." [8] Human society is the product of nature in the final analysis. Nature is the premise of human society and the material basis for human survival. "Man first depends on nature", "Man lives on the inorganic world", "Man can only live on these natural products physically" [9]. So a history of human development is a history of nature.

The law of natural development is closely related to the law of human social development, and they complement each other. The regulation of natural ecosystem needs the energy of the sun to drive the material exchange and circulation in nature. Once this system is broken, there will be a violent natural ecological reaction. For example, desertification, flood and other violent natural reaction, through this reaction to release and maintain the normal operation of natural ecosystems. Take the natural cycle of water for example.

The water cycle is a natural process with many links. Water vapor produced by surface water evaporation enters the atmosphere and moves with the atmosphere. Water vapor in the atmosphere comes mainly from the oceans, and some of it also comes from evaporation on the surface of the continents. Water vapor in the atmosphere condenses and falls from the warm equatorial regions with the flow of cold and warm air. Rehydrate dry land. Then it evaporates again, and so on, ensuring the balance of water in nature, thus ensuring the survival of people and animals.

Human society is also subject to this cycle. As a whole, human beings are constantly creating wealth. In the public ownership society, wealth is Shared by all and enjoyed by all. However, at a particular stage of private ownership and social development, social wealth gradually accumulates in a few or some groups, just as water in the water cycle accumulates in rivers, lakes and oceans. The unlimited accumulation of social wealth is bound to bring violent negative reaction to the society just like the desertification and flood in nature. Amartya Sen, a famous rights poverty theorist, analyzed from the perspective of rights method and believed that the fundamental cause of poverty was that the poor at the bottom of society lost the ownership of basic means of production and the ability to carry out production. In fact, the causes of poverty are very complicated. Poverty of rights is only one aspect that leads to poverty, but no matter what causes poverty, it is more or less related to social rights. Therefore, redistribution of wealth through state power is like evaporation and precipitation in the water cycle to maintain social balance.

\section{The Realistic Necessity of Poverty Alleviation}

1) The need to build a harmonious society. Mankind has just entered the $21^{\text {st }}$ century. On the morning of September 11, 2001, two hijacked civilian airliners crashed into the world trade center Building 1 and the world trade center Build- 
ing 2 respectively in New York, the United States. Another hijacked airliner crashed into the pentagon in Washington, causing partial structural damage and collapse. After the incident, the United States launched the "War on Terror", invaded Afghanistan to eliminate the Taliban who were hiding al-qaeda terrorists, and passed the United States patriot act. On October 7, 2001, President Bush announced the beginning of a military offensive in Afghanistan. The killing of Osama bin laden, however, did not bring peace, and terrorist attacks around the world continued unabated, making it the biggest headache in the developed world.

In essence, the causes of terrorist activities are racial discrimination and the unfairness of existing international rules. However, the root causes of terrorist activities are hunger, poverty and the lack of civilization. The cause of poverty is the unbalanced development of society, and poverty is the breeding ground for terrorists. Without extreme poverty, there would be no terrorists, and there would be no room for terrorists as tools of terrorist activities. Poverty alleviation is an effective way to redistribute social wealth and eliminate absolute poverty. It is also a good medicine to maintain social stability and balance. Therefore, it is also a necessary condition to build a harmonious society.

2) The essence of socialism. Marx believed that before the realization of communism, human society had to go through a transition from capitalism to communism, which Lenin later called the "socialist stage". In a socialist society it is "a social form based on the fundamental principle of the comprehensive and free development of every individual" [10]. "The free development of everyone is the condition for the free development of all." [11] Engels believed that socialism "not only could guarantee all members of society an abundant and increasingly abundant material life, but also could guarantee their full development and application of physical and intellectual freedom" [12], "which were a leap from the kingdom of necessity to the kingdom of freedom" [13]. Therefore, in the view of Marxism, socialism should be: "while ensuring the extremely high development of social labor productivity, but also to ensure the most comprehensive human development of such an economic form." [14] In his exploration of the construction of socialism with Chinese characteristics, Deng Xiaoping pointed out that the essence of socialism is to liberate the productive forces, develop the productive forces, eliminate exploitation, eliminate polarization and eventually achieve common prosperity. "Eliminating poverty, improving people's livelihood and achieving common prosperity are the essential requirements of socialism," [15] Xi said more explicitly. "Poverty is not socialism. If the poverty-stricken areas remain poor for a long time, their appearance will not be changed and their people's lives will not be significantly improved, then the superiority of China's socialist system will not be reflected, and that will not be socialism [16].

3) The need to complete the building of a moderately prosperous society in all respects. To complete the building of a moderately prosperous society in all respects is the requirement for realizing the two centenary goals and the only way 
to achieve the great rejuvenation of the Chinese nation. Building a moderately prosperous society in all respects leaves no one behind. This is the solemn commitment of the communist party of China. Building a moderately prosperous society in all respects is a leading strategic goal in the four-pronged comprehensive strategic plan. The Chinese dream of a moderately prosperous society in all respects and the Chinese dream of a moderately prosperous society in all respects are interconnected. "The most arduous and arduous task in building a moderately prosperous society in all respects lies in the countryside, especially in poor areas. Without a moderately prosperous society in the countryside, especially in poor areas, we will not be able to complete the building of a moderately prosperous society in all respects." [17]

\section{Conclusion}

In conclusion, deeply rooted in the social practice, precision poverty alleviation is a necessary measure for self-repairing and self-improvement of a society, which accords with the social development. It is vital in the course of building a moderately prosperous society in all respects and socialism with Chinese characteristics since reform and opening-up. Therefore, the Cadres and the masses who are fighting in the front-line of poverty alleviation should carefully understand the spirit of General Secretary Xi Jinping's speech, fully understand the importance and necessity of targeted poverty alleviation, resolutely win the battle against poverty with firm determination, conviction of victory and spirit of "embroidery", and strive for the great rejuvenation of the Chinese!

\section{Conflicts of Interest}

The author declares no conflicts of interest regarding the publication of this paper.

\section{References}

[1] Xi Went to West Hunan Province to Investigate Poverty Alleviation Efforts. XinHuaNet, 2013-11-03. http://cpc.people.com.cn/n/2013/1104/c64094-23421342-8.html

[2] Xie, P.A. (2016) Philosophical Thinking on "Precision Poverty Alleviation". Journal of Guangxi Institute of Political Science and Law Management, 25.

[3] Wang, S.T. (2014) Brief Talk on Precision Poverty Alleviation. http://blog.sina.com.cn/s/blog_599a3d490101k6od.html

[4] Li, K. and Ye, X. (2015) Rural Precision Poverty Alleviation: Theoretical Basis and Practical Situation Analysis. Journal of Fujian Institute of Administrative, No. 2.

[5] Wang, S. and Guo, Z. (2015) On Precise and Clever Poverty in China. Guizhou Social Science, No. 5.

[6] Vice Premier Wang Yang Speaks at a Symposium on Poverty Alleviation Assessment and Assessment, Jan. 14, 2017.

[7] The Editorial Advisory Board of Study and Question on Documents of the 2016 NPC and CPPCC (2016) Study and Question on Documents of the 2016 NPC and 
CPPCC. People's Publishing House, Beijing, 74.

[8] Marx and Engels (1995) The Complete Works of Marx and Engels. Vol. 42, People's Publishing House, Beijing, 167.

[9] Marx and Engels (1995) The Complete Works of Marx and Engels. Vol. 42, People's Publishing House, Beijing, 95.

[10] Marx (2004) Das Kapital. Vol. 1, People’s Publishing House, Beijing, 683.

[11] Marx and Engels (1995) Selections of Marx and Engels. Vol. 1, People's Publishing House, Beijing, 294.

[12] Marx and Engels (1995) Selections of Marx and Engels. Vol. 3, People's Publishing House, Beijing, 757.

[13] Marx and Engels (1995) Selections of Marx and Engels. Vol. 3, People's Publishing House, Beijing, 758.

[14] Feng, Z., et al. (2002) Marx’s Theory of “World History” and Globalization. People's Publishing House, Beijing, 118-119

[15] People's Daily on December 31, 2012.

[16] Liu, Y. (2014) Winning the Battle Against Poverty to Complete the Building of a Moderately Prosperous Society in All Respects-Thoroughly Studying and Implementing the Spirit of Comrade Xi Jinping's Important Speech on Poverty Alleviation and Development. People's Daily, 9 April 2014.

[17] We Will Keep the Safety of the People in Mind at All Times, and Keep the Warmth of the Party and Government in Our Homes. GuangMing Daily, 31 December 2012. 